\title{
Low Salt Intake Down-regulates the Guanylin Signaling Pathway in Rat Distal Colon
}

\author{
ZHIPING LI ${ }^{\star}, \ddagger$, JOSHUA W. KNOWLES ${ }^{\star}$, DOMINIQUE GOYEAU ${ }^{\star}$, SUBHASH PRABHAKAR ${ }^{*}$, \\ DOUGLAS B. SHORT ${ }^{*}$, ASHLEY G. PERKINS ${ }^{*}$, and MICHAEL F. GOY ${ }^{*}, \ddagger$ \\ "Department of Physiology, University of North Carolina, Chapel Hill, North Carolina \\ ‡Center for Gastrointestinal Biology and Disease, University of North Carolina, Chapel Hill, North \\ Carolina
}

\section{Abstract}

Background \& Aims-Guanylin, an endogenous gastrointestinal peptide, causes the translocation of $\mathrm{NaCl}$ from interstitial fluid to the intestinal lumen. The aim of this study was to examine whether changes in dietary salt intake lead to compensatory changes in expression of the guanylin signaling pathway.

\begin{abstract}
Methods-Rats received low-, normal-, or high-sodium diets for 1 week. Colonic guanylin expression was evaluated by Western and Northern blotting, rates of guanylin secretion by measuring biologically active guanylin released into the medium from colon explants, and expression of the guanylin receptor (C-type guanylate cyclase) by Northern blotting and bioassay.

Results-By every criterion, the low-salt diet reduced expression of guanylin to $30 \%-40 \%$ of the level found in control animals. Guanylin receptor expression was also decreased, although less dramatically and with a lower statistical significance. For both guanylin and guanylin receptor, the high-salt diet had no significant effect on expression.
\end{abstract}

Conclusions-The data support the hypothesis that the guanylin pathway is down-regulated as an adaptive response to salt restriction.

\begin{abstract}
Intake and excretion of sodium are normally precisely balanced to achieve a stable plasma sodium concentration and constant extracellular fluid volume. When the concentration of sodium fluctuates by more than a few percent, endocrine pathways restore normal equilibrium by altering the rates at which sodium is absorbed or excreted. The principal tissues that mediate sodium absorption and excretion are the renal and intestinal epithelia.

The response to sodium deficit is controlled primarily by the renin/angiotensin/aldosterone system. This hormonal axis enhances intestinal absorption of dietary sodium and reduces renal excretion of filtered sodium.1,2 On the other side of the salt balance equation, a pair of related peptides, urodilatin and atrial natriuretic peptide, reduce sodium absorption and enhance sodium excretion in response to excessive salt intake.3-5
\end{abstract}


Atrial natriuretic peptide and urodilatin share a common receptor, a membrane-bound guanylate cyclase called GCA (A-type guanylate cyclase). 6 This receptor is actually a member of a larger family of membrane-associated receptor/guanylate cyclases. Recently, a new member of this family was cloned7 and shown to be expressed at high levels in the intestinal epithelium.8,9 This new receptor/cyclase was given the name GCC (C-type guanylate cyclase). It was originally identified as the target of a diarrhea-inducing enterotoxin, called STa (stable toxin type A).7 However, GCC has subsequently been shown to serve as the receptor for a pair of endogenous gastrointestinal peptides called guanylin and uroguanylin.10 Application of STa, guanylin, or uroguanylin to the intestinal epithelium activates electrogenic chloride secretion, which drives the paracellular movement of sodium into the lumen. In addition, activation of GCC inhibits epithelial sodium uptake in the intestine by an as yet unspecified mechanism.11 Although renal expression of GCC has not been shown directly, binding studies indicate that it (or a related receptor) is also present in the epithelial cells of the renal tubule.12 Furthermore, application of GCC-specific ligands to the kidney increases urinary sodium excretion. 13

Taken together, these results suggest that atrial natriuretic peptide, urodilatin, guanylin, and uroguanylin comprise an endocrine system with natriuretic actions in the kidney and the intestine. However, there is presently no direct evidence supporting a role for the guanylin/ uroguanylin/GCC signaling pathway in salt homeostasis. In our current study, we measured the expression of guanylin and GCC in animals fed different sodium loads. We focused our analysis on distal colon for two reasons. First, guanylin and GCC expression are normally high in this tissue. 8 Second, this is the region of the gastrointestinal tract most likely as a target for hormonal regulation of salt transport. It provides the intestine's last opportunity to capture dietary salt when intake is limited and a potential route for excretion of salt when intake is elevated. Our studies show that colonic expression of guanylin is decreased when dietary sodium is restricted. GCC expression shows a similar trend, although the effect is smaller and less statistically significant. We propose that these changes in expression represent a compensatory mechanism that helps the animal adapt to demands imposed by inconsistent sodium intake.

\section{Materials and Methods}

\section{Tissue Preparation}

Age-matched male Sprague-Dawley rats (150-175 g) were assigned randomly to one of three treatment groups (low, normal, or high salt intake) and given free access to food (Harlan, Indianapolis, IN) and drinking water for 1 week. Previous studies have indicated that 1 week is sufficient for the renal salt-handling mechanisms to achieve new steady-state levels. 14 The low-salt diet contained $0.08 \%$ sodium as determined by atomic absorption spectrometry. Normal- and high-salt diets were supplemented with $\mathrm{NaCl}$ to $1 \%$ and $4 \%$, giving final net sodium concentrations of $0.47 \%$ and $1.65 \%$, respectively.

Rats were then killed by exposure to $\mathrm{CO}_{2}$. Distal colons were removed and either frozen for RNA and peptide extraction or placed in Ringer's-glucose solution $\left(130 \mathrm{mmol} / \mathrm{L} \mathrm{Na}^{+}, 120\right.$ $\mathrm{mmol} / \mathrm{L} \mathrm{Cl}^{-}, 25 \mathrm{mmol} / \mathrm{L} \mathrm{HCO}_{3}{ }^{-}, 1.2 \mathrm{mmol} / \mathrm{L} \mathrm{Mg}^{2+}, 1.2 \mathrm{mmol} / \mathrm{L} \mathrm{Ca}^{2+}, 2.4 \mathrm{mmol} / \mathrm{L}$ 
$\mathrm{K}_{2} \mathrm{HPO}_{4}, 0.4 \mathrm{mmol} / \mathrm{L} \mathrm{KH}_{2} \mathrm{PO}_{4}$, and $10 \mathrm{mmol} / \mathrm{L}$ glucose bubbled with $95 \% \mathrm{O}_{2}-5 \% \mathrm{CO}_{2}$ at $37^{\circ} \mathrm{C}$ ) for bioassay and secretion experiments.

\section{Northern Blotting}

Total RNA was extracted from frozen tissues, and Northern blots were performed with guanylin and GCC probes as previously described. 8 The blots were then stripped (60 minutes in $50 \%$ formamide at $65^{\circ} \mathrm{C}$ and 15 minutes in $0.1 \times$ standard saline citrate plus $0.1 \%$ sodium dodecyl sulfate 1 at $55^{\circ} \mathrm{C}$ ) and rehybridized with a probe synthesized from a $\beta$-actin template (Clontech, Palo Alto, CA). Autoradiograms were quantitated by densitometry using NIH Image (National Institutes of Health, Bethesda, MD). Exposure times were adjusted to keep signal densities within the linear range of the film.

\section{Western Blotting}

For the preparation of peptide-containing extracts, the smooth muscle layer was stripped from the mucosal/submucosal layer and discarded before freezing. Frozen tissues were homogenized in HEPES buffer $(25 \mathrm{mmol} / \mathrm{L} \mathrm{pH} \mathrm{7.4)} \mathrm{containing} \mathrm{a} \mathrm{mixture} \mathrm{of} \mathrm{protease}$ inhibitors, as previously described.15 After assaying protein levels (Bradford assay; BioRad, Richmond, CA), samples containing $40 \mu \mathrm{g}$ of protein were analyzed by Western blotting using antibodies 2538 (raised against rat preproguanylin 24-37) and 6240 (raised against rat preproguanylin $85-99$ ). Antibody 6240 was kindly provided by Dr. Sharon Milgram (Chapel Hill, NC). The blots were then incubated with a horseradish peroxidasecoupled secondary antibody (goat anti-rabbit; Boehringer-Mannheim, Indianapolis, IN) and chemiluminescence reagent (Amersham, Arlington Heights, IL) and exposed to film. Film images were quantitated as described above using linear exposure times.

\section{Histology and Immunocytochemistry}

Animals were anesthetized with urethane (1.6 g/kg intraperitoneally), cleared with heparinized $0.9 \%$ sodium chloride in $0.01 \mathrm{~mol} / \mathrm{L}$ phosphate buffer, $\mathrm{pH} 7.4$, and fixed with $4 \%$ paraformaldehyde $-0.18 \%$ picric acid in $0.16 \mathrm{~mol} / \mathrm{L}$ phosphate buffer, $\mathrm{pH}$ 7.2. Tissue was postfixed, sectioned, and stained with H\&E16 or processed for immunocytochemistry with antibody 2538 as previously described.15

\section{GCC Bioassay}

Distal colon was subdivided into small pieces $(\sim 5 \times 5 \mathrm{~mm})$ and incubated in Ringer'sglucose solution containing $0.5 \mathrm{mmol} / \mathrm{L}$ isobutyl methylxanthine (IBMX) for 30 minutes. STa was then added to the appropriate vials for 30 minutes. Reactions were stopped by freezing tissue pieces on dry ice. Each individual piece was then homogenized in 6\% trichloroacetic acid (TCA) and centrifuged to separate TCA-insoluble protein from TCAsoluble guanosine $3^{\prime}, 5^{\prime}$-cyclic monophosphate (cGMP). The pellet was dissolved in $1 \mathrm{~N}$ $\mathrm{NaOH}$ and assayed for protein content (Bio-Rad Bradford assay). The cGMP level was quantitated by radioimmunoassay using standard procedures 15 and was normalized to protein to correct for small differences in the sizes of the original pieces of tissue. 


\section{Guanylin Secretion Studies}

A 4-5-cm length of distal colon was removed from the animal after death. The tissue was opened longitudinally, rinsed, and incubated in oxygenated Ringer's-glucose solution at $37^{\circ} \mathrm{C}$ for 60 minutes. The incubation medium was then fractionated by reverse-phase highperformance liquid chromatography (HPLC) (HR5/5 C-18 column; Pharmacia, Piscataway, NJ) as shown in Figure 4. HPLC fractions were dried, resuspended in Hank's balanced salt solution plus $1 \mathrm{mmol} / \mathrm{L}$ IBMX, and assayed for guanylin-like activity in a standard T84 cell bioassay, as previously described.17 To calibrate the column, synthetic rat guanylin 15 (a gift from Dr. Ding Chuang, Peninsula Laboratories), opossum uroguanylin (a gift from Dr. Leonard Forte, Columbia, MO), STa (Sigma), and partially purified rat proguanylin were chromatographed using the same elution profile. The HPLC fractions were then either assayed on T84 cells (guanylin 15, uroguanylin, and STa) or analyzed by Western blotting (proguanylin).

\section{Statistical Analysis}

The reported sample size (n) indicates the number of animals in each treatment group. For the Northern blot and secretion studies, one measurement was made from each animal, and these measurements were used to determine the mean, SEM, and $P$ value for each treatment group. For the Western blot and GCC bioassay studies, 5 and 15 independent measurements were made from each animal, respectively, and used to calculate the average value for each animal. The averaged values were then used to determine the mean, SEM, and $P$ value for each treatment group. Student's two-tailed $t$ test was used to calculate $P$ values, and differences between treatment groups were defined as statistically significant with $P$ values of $<0.05$.

\section{Results}

\section{Expression of Guanylin and GCC Messenger RNAs}

Animals were maintained on defined diets containing low, normal, or high sodium levels for 1 week, and Northern blots were performed to quantitate expression of guanylin, GCC, and $\beta$-actin. The representative blots in Figure $1 A$ show that each of the probes hybridizes exclusively to a single transcript of the appropriate molecular weight. Initial analysis showed that $\beta$-actin expression is unaffected by salt intake (data not shown). Thus, each of our measurements of guanylin or GCC messenger RNA (mRNA) expression has been normalized to the amount of $\beta$-actin mRNA determined in the same sample on the same blot to correct for variations in the amount of RNA loaded from each sample.

As shown in Figure $1 B$, animals maintained on the low-sodium diet for 1 week have a significant decrease in expression of guanylin mRNA (to approximately $40 \%$ of control). In contrast, after 1 week on the high-sodium diet, expression of guanylin mRNA is unaffected. GCC expression follows the same trend (Figure 1C), although the difference between lowand normal-salt treatment groups did not reach our arbitrary criterion for statistical significance. 


\section{Expression of Proguanylin}

Two biologically active forms of guanylin have been recognized: guanylin 15, a 15-amino acid peptide purified from intestinal extracts, 17 and guanylin 14, an $\mathrm{N}$-terminal truncation of guanylin 15 that was subsequently isolated from intestinal perfusates.18 However, Western blot 15,19 and peptide expression20 studies indicate that guanylin is initially synthesized in the form of a biologically inactive 10-kilodalton propeptide, which has the guanylin 15 and guanylin 14 sequences at its $\mathrm{C}$ terminus. To measure guanylin propeptide levels in extracts of distal colon, we performed Western blots using two different antibodies. Antibody 2538 is directed against a region near the $\mathrm{N}$ terminus of the propeptide, and antibody 6240 is directed against a region just adjacent to the biologically active $\mathrm{C}$ terminus. Previous work has shown that antibody 2538 is highly specific, recognizing only the 10-kilodalton guanylin propeptide in extracts of intestinal tissue. 15 As shown in figure $2 A$, antibody 6240 recognizes the same 10-kilodalton propeptide and additionally cross-reacts with two uncharacterized proteins at 29 and 31 kilodaltons.

Figure $2 B$ shows proguanylin levels in each of the treatment groups as measured with antibody 6240. Identical results are obtained with antibody 2538 (data not shown). These observations are fully compatible with the gene expression experiments of Figure $1 B$ : proguanylin levels are decreased to approximately $30 \%$ of control in animals on the low-salt diet but remain comparable to control levels in animals on the high-salt diet. To verify the specificity of this effect, we analyzed expression of the 29- and 31-kilodalton proteins recognized by antibody 6240 and found that they are not affected by salt intake (data not shown).

To see if changes in salt intake are accompanied by changes in tissue morphology, we analyzed sections of distal colon obtained from animals on each type of diet (data not shown). No histological differences were detected between treatment groups after staining with H\&E. We also immunostained sections with antibody 2538 to examine guanylin expression at the cellular level. When treatment groups were compared, no obvious differences were apparent in the distribution or frequency of guanylin-expressing cells. Unfortunately, because of the nonquantitative nature of this technique, it was not possible to show decreased staining levels in the low-salt group relative to the other groups.

\section{Expression of GCC Cyclase Activity}

In evaluating GCC expression at the receptor level, we used a bioassay that measures the ability of explants of distal colon to increase cGMP levels in response to STa, a potent and specific GCC ligand. As shown in Figure 3, GCC-mediated responses are significantly decreased to about $70 \%$ of control by the low-salt diet but are not affected by the high-salt diet. These results seem to parallel the findings of GCC mRNA expression studies shown in Figure $1 C$ and may thus reflect a common underlying cause. However, given uncertainty about the significance of the observed differences in GCC mRNA expression, it is also possible that the effects of low salt intake on receptor activity occur by a mechanism that is independent of gene transcription. For example, the low-salt diet could induce changes in the phosphorylation state of GCC, which would alter its activity without any change in receptor number.21,22 


\section{Analysis of Guanylin Secretion}

Figure $2 B$ shows that long-term low salt intake reduces the steady-state level of proguanylin in the distal colon. However, in a physiological context, a decrease in peptide content would be most meaningful if it, in turn, specified a decrease in the rate of peptide secretion. To see if this might be the case, we obtained colonic tissue explants from animals maintained on each diet, organ cultured the explants for 60 minutes, and measured the amount of guanylin released into the incubation medium.

As mentioned above, the biologically active forms of guanylin are thought to be guanylin 15 and guanylin 14. Because these fragments are too small to detect by Western blotting, we measured their levels by applying our samples to a GCC-expressing cell line and quantitating the increase in intracellular cGMP levels.

We used two criteria to ensure specificity in this bioassay. First, our reporter cell line (T84) expresses significant amounts of GCC17 but very low amounts of the other membraneassociated receptor/guanylate cyclases. 23 Second, to distinguish guanylin-related peptides from other known GCC ligands (uroguanylin and STa), we applied our samples to a reversephase HPLC column and used an elution protocol that successfully resolves these peptides from one another. Figure 4 shows that two peaks of biological activity are secreted by explants obtained from all three treatment groups. The major peak coelutes with a synthetic guanylin 15 standard and is clearly distinct from uroguanylin or STa. The minor peak does not correspond to any known peptide. It could be an alternate cleavage product derived from proguanylin or prouroguanylin or it could be some other as yet undescribed molecule. The fact that colonic explants secrete guanylin but not uroguanylin is consistent with the observed expression patterns of the two peptides: rat colon expresses relatively high levels of guanylin mRNA24 and propeptide15 but almost undetectable levels of uroguanylin mRNA and propeptide. 25

Secretion of biologically active material is reduced after 1 week of low salt intake. In the case of the major peak, the reduction is statistically significant $(P=0.037)$. The rate of secretion of the minor peak also appears to be reduced, although the significance $(P=0.059)$ is slightly above our arbitrary criterion of 0.05 . As with all other parameters evaluated in this study, 1 week of elevated salt intake has no effect on the rate of secretion of either of these peaks.

\section{Discussion}

Although salt homeostasis is primarily considered the function of the kidney, important contributions are also made by the intestine. First, the intestine is the only organ that can absorb salt from outside the body, thus replacing the electrolytes lost in sweat and urine. Second, the natriuretic response of the kidney to an increased sodium load occurs faster when the load is delivered orally than when the same load is delivered intravenously.26 This suggests that the intestine is capable of providing the kidney with information about dietary salt intake, although the nature of the signal is still unknown. Because guanylin and uroguanylin are primarily synthesized in the intestine but can induce natriuresis in the 
kidney, 10 they are in fact good candidates for such a signal. Detection of both guanylin and uroguanylin in the blood 19,27,28 and the urine29 supports this idea.

In addition, these peptides are likely to regulate local salt transport within the intestine itself. First, the guanylin/uroguanylin receptor (GCC) is present at considerably higher levels in the intestine than in any other organ.7 This receptor is expressed exclusively in epithelial cells, 8,9 and its luminal orientation30 suggests that it functions to detect local signals rather than blood-borne signals. Second, immunocytochemical studies show prominent guanylin expression in intestinal goblet cells, 15,31 which are specialized for vectorial secretion into the intestinal lumen rather than into the blood. Indeed, studies with perfused intestinal tissue show that the rate of luminal release of guanylin is much higher than the rate of vascular release.18,32 Third, guanylin and uroguanylin have potent natriuretic actions on the intestinal epithelium: both peptides induce electrogenic chloride secretion, which drives the luminal accumulation of sodium and water.10

Not surprisingly, salt intake is a key parameter that controls the expression of hormones, receptors, and downstream effectors that are involved in salt transport. Given the involvement of guanylin and uroguanylin in epithelial salt secretion in several different tissues, we decided to investigate whether expression of this signaling pathway is affected by salt intake. Uroguanylin-specific reagents are not currently available for rats. However, a combination of complementary DNA probes, antibodies, and bioassays provided us with several independent ways to measure the expression of the rat isoforms of guanylin and its receptor, GCC. Because guanylin and GCC are expressed at particularly high levels in the colon and because distal colon is an important player in regulated salt and water transport within the gastrointestinal tract,33 we focused our studies on this tissue.

As described above, we found that low salt consumption significantly depresses the levels of guanylin mRNA, guanylin propeptide, and GCC-mediated cGMP synthesis as well as the rate of release of biologically active guanylin from tissue explants. Thus, essentially all of the parameters that control the status of the guanylin signaling pathway are down-regulated in parallel. This is consistent with other physiological changes that occur during periods of salt restriction: low salt intake drives the distal colon to become a sodium scavenging tissue, and suppression of guanylin-induced sodium efflux would eliminate a mechanism that opposes sodium absorption.

Many of the responses induced by low salt intake are controlled by aldosterone, a steroid hormone that acts through specialized receptors to regulate gene expression.1,14 Two classes of steroid receptor mediate the effects of aldosterone: a high-affinity mineralocorticoid receptor and a lower affinity glucocorticoid receptor, both of which are expressed in distal colon.34,35 Once a steroid has bound to mineralocorticoid receptor or glucocorticoid receptor, the hormone-receptor complex interacts with steroid hormone response elements in the nucleus to either enhance or repress transcription of specific genes. It is of interest to note that a classical glucocorticoid response element has been identified in the promoter region of the guanylin gene. 36 Thus, it is tempting to speculate that an aldosterone-based mechanism is responsible for the changes in guanylin expression that we have observed, although further experiments are required to verify this idea. 
Our studies also show that there is no change in guanylin or GCC expression when animals are placed on a high salt load. It is possible that some response could be induced by higher salt concentrations, or observed after longer or shorter treatment times. However,

physiologically, it might actually make more sense if this did not happen. Unlike the kidney, the intestine has no mechanism for concentrating salt. Thus, using the intestine to dispose of excess salt would lead to simultaneous loss of water, which would be counterproductive in an animal that is ingesting an excessive salt load.

Several previous studies 18,32 have analyzed secretion of guanylin-like peptides from internally perfused small intestine. The material detected in these studies corresponds to guanylin 15 and guanylin 14. Our data, shown in Figure 4, show that, similar to the intestine, the colon also secretes biologically active material corresponding to either guanylin 15 or guanylin 14 (it is doubtful that our HPLC protocol would clearly separate these two peptides). Additionally, our data show that the rate of release of this biologically active material is roughly proportional to the tissue content of proguanylin. We cannot tell if intact proguanylin might also be simultaneously released in our experimental paradigm because the low biological activity of the propeptide precludes its detection by bioassay.20,37,38 However, our data do show the presence of a second peak of biological activity, distinct from proguanylin and from all known forms of biologically active guanylin. This material is not uroguanylin or STa because it fails to elute with our uroguanylin and STa standards; its identity remains unclear. Perhaps the most interesting aspect of our secretion studies is the observation that colonic explants, isolated from extrinsic neural and hormonal inputs, tonically release two peaks of guanylin-like activity and that the rate of release of both peaks reflects the animal's history of salt consumption. It would be of interest to repeat these studies, using a more intact preparation, to see whether these results are modified when extrinsic inputs are maintained.

In summary, we have found that the guanylin signaling pathway is down-regulated by low salt intake. The most consistent effects are observed on guanylin itself: levels of guanylin mRNA, guanylin propeptide, and secreted bioactive guanylin are all significantly reduced to about $40 \%$ of the levels measured in matched controls. In parallel, the guanylin receptor (GCC) also seems to be down-regulated, although less strongly: both GCC-mediated cGMP synthesis and GCC mRNA levels are decreased to $60 \%-70 \%$ of control (although, due to scatter in the data, the latter effect failed to reach statistical significance). Taken together, these responses correlate well with the physiological requirements imposed by restricted salt intake, because one direct consequence of decreasing activity in the guanylin pathway should be a net increase in salt absorption. In contrast, high salt intake has no effect on guanylin or GCC expression in the intestine. However, it is possible that high salt intake might affect expression of guanylin or GCC in other tissues. Also, it is possible that high salt intake may act on uroguanylin rather than on guanylin. In fact, high concentrations of uroguanylin in urine, relative to guanylin, 10 make it the better candidate for an intestinally derived stimulus that induces renal natriuresis and thus a more likely target for regulation during salt loading. 


\section{Acknowledgments}

Supported by a grant from the National Institutes of Health (NIH) (to M.F.G.) and a pilot/feasibility grant funded by the UNC Center for Gastrointestinal Biology and Disease under NIH Center grant DK34987 (to Z.L.).

The authors thank Julia Vorobiov of the CGIBD Immunoassay Core for assistance with radioimmunoassays, Joe Deveau for help with RNA purification, Sharon Milgram for providing us with antibody 6240, and Kathleen Dunlap, Bill Arendshorst, Jim Faber, and Kit Purdy for commenting on the manuscript before publication.

\section{Abbreviations used in this paper}

$\begin{array}{ll}\text { GCA } & \text { A-type guanylate cyclase } \\ \text { GCC } & \text { C-type guanalytate cyclase } \\ \text { HPLC } & \text { high-performance liquid chromatography } \\ \text { IBMX } & \text { isobutyl methylxanthine } \\ \text { STa } & \text { stable toxin type A } \\ \text { TCA } & \text { trichloroacetic acid }\end{array}$

\section{References}

1. Horisberger JD, Rossier BC. Aldosterone regulation of gene transcription leading to control of ion transport. Hypertension. 1992; 19:221-227. [PubMed: 1372288]

2. Wehling M. Nongenomic aldosterone effects: the cell membrane as a specific target of mineralocorticoid action. Steroids. 1995; 60:153-156. [PubMed: 7792803]

3. Scavone C, Scanlon C, McKee M, Nathanson JA. Atrial natriuretic peptide modulates sodium and potassium-activated adenosine triphosphatase through a mechanism involving cyclic GMP and cyclic GMP-dependent protein kinase. J Pharmacol Ex Ther. 1995; 272:1036-1043.

4. McCoy DE, Guggino SE, Stanton BA. The renal cyclic GMP-gated cation channel: its molecular structure and physiological role. Kidney Int. 1995; 48:1125-1133. [PubMed: 8569074]

5. Argenzio RA, Armstrong M. ANP inhibits $\mathrm{NaCl}$ absorption and elicits $\mathrm{Cl}$ secretion in porcine colon: evidence for cGMP and Ca mediation. Am J Physiol. 1993; 265:R57-R65. [PubMed: 8393628]

6. Drewett JG, Garbers DL. The family of gyanylyl cyclase receptors and their ligands. Endocrine Rev. 1994; 15:135-162. [PubMed: 7913014]

7. Schulz S, Green CK, Yuen PST, Garbers DL. Guanylyl cyclase is a heat-stable enterotoxin receptor. Cell. 1990; 63:941-948. [PubMed: 1701694]

8. Li Z, Goy MF. Peptide-regulated guanylate cyclase pathways in rat colon: in situ localization of GCA, GCC, and guanylin mRNA. Am J Physiol. 1993; 265:G394-G402. [PubMed: 8103637]

9. Cohen MB, Mann EA, Lau C, Henning S, Giannella RA. A gradient in expression of the Escherichia coli heat-stable enterotoxin receptor exists along the villus-to-crypt axis of rat small intestine. Biochem Biophys Res Commun. 1992; 186:483-490. [PubMed: 1378729]

10. Forte LR, Hamra FK. Guanylin and uroguanylin: intestinal peptide hormones that regulate epithelial transport. News Physiol Sci. 1996; 11:17-24.

11. Donowitz, M.; Welsh, MJ. Regulation of mammalian small intestinal electrolyte secretion.. In: Johnson, LR., editor. Physiology of the gastrointestinal tract. 2nd ed.. Raven; New York: 1987. p. 1351-1379.

12. Forte LR, Krause WJ, Freeman RH. Escherichia coli enterotoxin receptors: localization in opossum kidney, intestine, and testis. Am J Physiol. 1989; 257:F874-F881. [PubMed: 2556042]

13. Fonteles MC, Greenberg RN, Currie MG, Forte LR. Guanylin and uroguanylin are GC-C binding intestinal peptide hormones with natriuretic and kaliuretic activity (abstr). J Invest Med. 1995; 43:395A. 
14. Laragh, JH.; Sealey, JE. Renin-angiotensin-aldosterone system and the renal regulation of sodium, potassium, and blood pressure homeostasis.. In: Windhager, EE., editor. Handbook of physiology. Section 8: renal physiology. 2nd ed.. Oxford University; Oxford, England: 1992. p. 1409-1541.

15. Li Z, Taylor-Blake B, Light AR, Goy MF. Guanylin, an endogenous ligand for C-type guanylate cyclase, is produced by goblet cells in the rat intestine. Gastroenterology. 1995; 109:1863-1875. [PubMed: 7498651]

16. Luna, LG. Manual of histologic staining methods of the Armed Forces Institute of Pathology. 3rd ed.. McGraw-Hill; New York: 1968. p. 32-39.

17. Currie MG, Fok KF, Kato J, Moore RJ, Hamra FK, Duffin KL, Smith CE. Guanylin: an endogenous activator of intestinal guanylate cyclase. Proc Natl Acad Sci USA. 1992; 89:947-951. [PubMed: 1346555]

18. Kita T, Smith CE, Duffin KL, Fok KF, Currie MG. Characterization of bioactive guanylin released from rat small intestine (abstr). FASEB J. 1995; 9:A632.

19. Kuhn M, Raida M, Adermann K, Schulz-Knappe P, Gerzer R, Heim JM, Forssmann WG. The circulating bioactive form of human guanylin is a high molecular weight peptide $(10.3 \mathrm{kDa})$. FEBS Lett. 1993; 318:205-209. [PubMed: 8095028]

20. Schulz S, Chrisman TD, Garbers DL. Cloning and expression of guanylin. J Biol Chem. 1992; 267:16019-16021. [PubMed: 1379587]

21. Potter LR, Garbers DL. Dephosphorylation of the guanylyl cyclase-A receptor causes desensitization. J Biol Chem. 1992; 267:14531-14534. [PubMed: 1353076]

22. Wada A, Hasegawa M, Matsumoto K, Niidome T, Kawano Y, Hidaka Y, Padilla PI, Kurazono H, Shimonishi Y, Hirayama T. The significance of $\operatorname{Ser}^{1029}$ of the heat-stable enterotoxin receptor (STaR): relation of STa-mediated guanylyl cyclase activation and signaling by phorbol myristate acetate. FEBS Lett. 1996; 384:75-77. [PubMed: 8797807]

23. Chrisman TD, Schulz S, Potter LR, Garbers DL. Seminal plasma factors that cause large elevations in cellular cyclic GMP are C-type natriuretic peptides. J Biol Chem. 1993; 268:3698-3703. [PubMed: 8094083]

24. Wiegand RC, Kato J, Currie MG. Rat guanylin cDNA: characterization of the precursor of an endogenous activator of intestinal guanylate cyclase. Biochem Biophys Res Commun. 1992; 185:812-817. [PubMed: 1378267]

25. Li Z, Perkins AG, Peters MF, Campa MJ, Goy MF. Amino acid and cDNA sequences of a uroguanylin-like peptide purified from rat duodenum. Regul Pept. (in press).

26. Lennane RJ, Carey RM, Goodwin TJ, Peart WS. A comparison of natriuresis after oral and intravenous sodium loading in sodium-depleted man: evidence for a gastrointestinal or portal monitor of sodium intake. Clin Sci Mol Med. 1975; 49:437-440. [PubMed: 1192701]

27. Fan XH, Hamra FK, Freeman RH, Eber SL, Krause WJ, Lim RW, Pace VM, Currie MG, Forte LR. Uroguanylin: cloning of preprouroguanylin cDNA, mRNA expression in the intestine and heart and isolation of uroguanylin and prouroguanylin from plasma. Biochem Biophys Res Commun. 1996; 219:457-462. [PubMed: 8605009]

28. Nakazato M, Yamaguchi H, Kinoshita H, Kangawa K, Matsuo H, Chino N, Matsukura S. Identification of biologically active and inactive human uroguanylins in plasma and urine and their increases in renal insufficiency. Biochem Biophys Res Commun. 1996; 220:586-593. [PubMed: 8607808]

29. Hamra FK, Forte LR, Eber SL, Pidhorodeckyj NV, Krause WJ, Freeman RH, Chin DT, Tompkins JA, Fok KF, Smith CE, Duffin KL, Siegel NR, Currie MG. Uroguanylin: structure and activity of a second endogenous peptide that stimulates intestinal guanylate cyclase. Proc Natl Acad Sci USA. 1993; 90:10464-10468. [PubMed: 7902563]

30. Guarino A, Cohen MB, Overman G, Thompson MR, Giannella RA. Binding of E. coli heat-stable enterotoxin to rat intestinal brush borders and to basolateral membranes. Dig Dis Sci. 1987; 32:1017-1026. [PubMed: 3304888]

31. Cohen MB, Witte DP, Hawkins JA, Currie MG. Immunohistochemical localization of guanylin in the rat small intestine and colon. Biochem Biophys Res Commun. 1995; 209:803-808. [PubMed: 7733972] 
32. Moro F, Bernard C, Cuber JC. Release of guanylin from the isolated vascularly perfused rat ileum (abstr). Gastroenterology. 1996; 110:A348.

33. Powell, DW. Intestinal water and electrolyte transport.. In: Johnson, LR., editor. Physiology of the gastrointestinal tract. 2nd ed.. Raven; New York: 1987. p. 1267-1305.

34. Binder HJ, White A, Whiting D, Hayslett J. Demonstration of specific high affinity receptors for aldosterone in cytosol of rat colon. Endocrinology. 1986; 117:628-631. [PubMed: 2935388]

35. Bastl CP, Barnett CA, Schmidt TJ, Litwack G. Glucocorticoid stimulation of sodium absorption in colon epithelia is mediated by corticosteroid IB receptor. J Biol Chem. 1984; 259:1186-1195. [PubMed: 6693382]

36. Sciaky D, Kosiba JL, Cohen MB. Genomic sequence of the murine guanylin gene. Genomics. 1994; 24:583-587. [PubMed: 7713512]

37. Garcia KC, De Sauvage FJ, Struble M, Henzel W, Reilly D, Goeddel DV. Processing and characterization of human proguanylin expressed in Escherichia coli. J Biol Chem. 1993; 268:22397-22401. [PubMed: 7901199]

38. Hamra FK, Fan XH, Krause WJ, Freeman RH, Chin DT, Smith CE, Currie MG, Forte LR. Prouroguanylin and proguanylin: purification from colon, structure, and modulation of bioactivity by proteases. Endocrinology. 1996; 137:257-265. [PubMed: 8536621] 

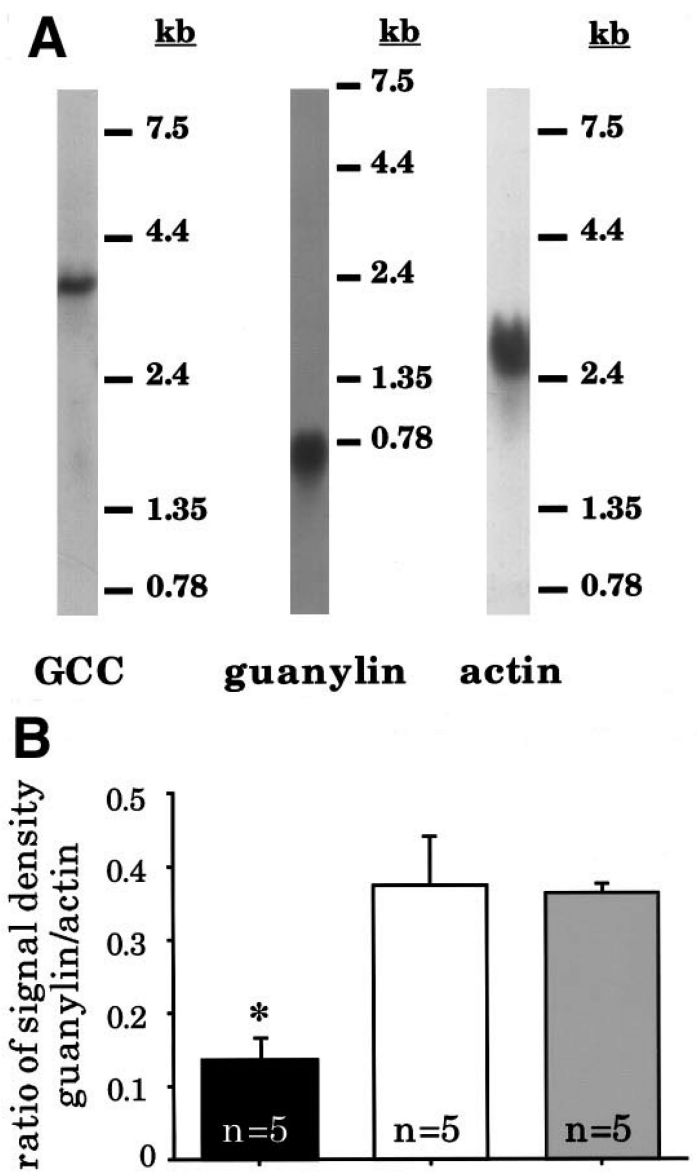

LOW NORMAL HIGH

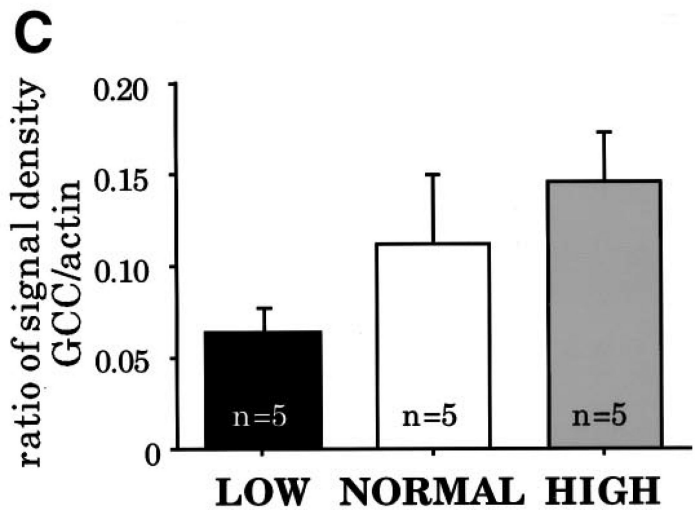

Figure 1.

Northern analysis of RNA obtained from rats maintained on low-, normal-, or high-salt diets. $(A)$ Representative blots showing hybridization patterns obtained with complementary DNA probes for GCC, guanylin, and $\beta$-actin. Molecular weights are indicated to the right of each blot. (B) Densitometric quantitation of guanylin mRNA levels. Expression is significantly reduced in rats from the low-salt group ( ${ }^{*} P<0.03$ compared with control). $(C)$ Densitometric quantitation of GCC mRNA levels. Expression is reduced in low-salt rats, 
although the effect is not statistically significant $(P<0.27$ compared with control). All RNA measurements are normalized to $\beta$-actin levels. 


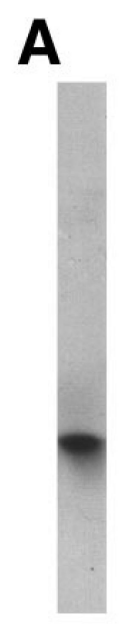

2538

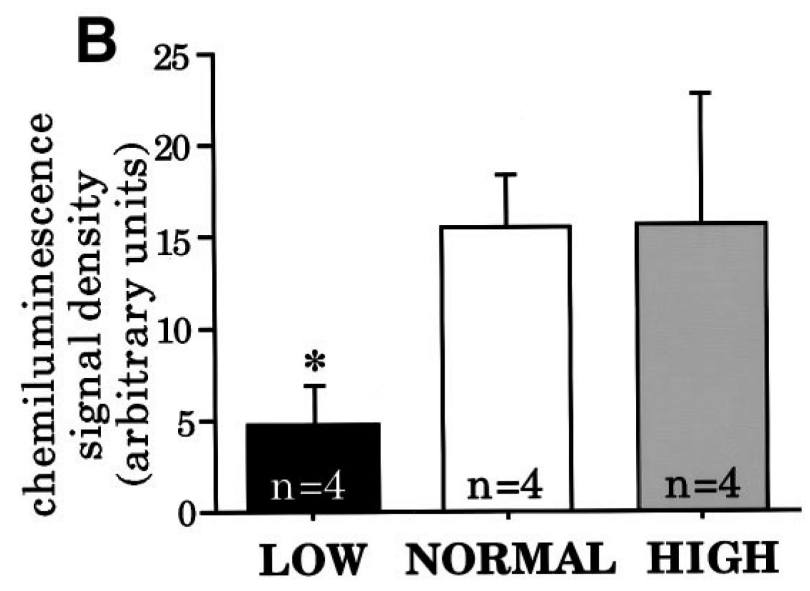

Figure 2.

Western analysis of peptide extracts obtained from rats kept on low-, normal-, or high-salt diets. (A) Representative blots performed on identical aliquots of a single extract from a rat maintained on a normal-salt diet showing immunoreactive polypeptides detected by antibodies 2538 and 6240. Molecular weights are indicated on the right. (B) Quantitation of proguanylin levels (10-kilodalton immunoreactive protein) using antibody 6240.

Comparable results are obtained with antibody 2538. Proguanylin expression is significantly reduced in rats from the low-salt group $(* P<0.05$ compared with control). 


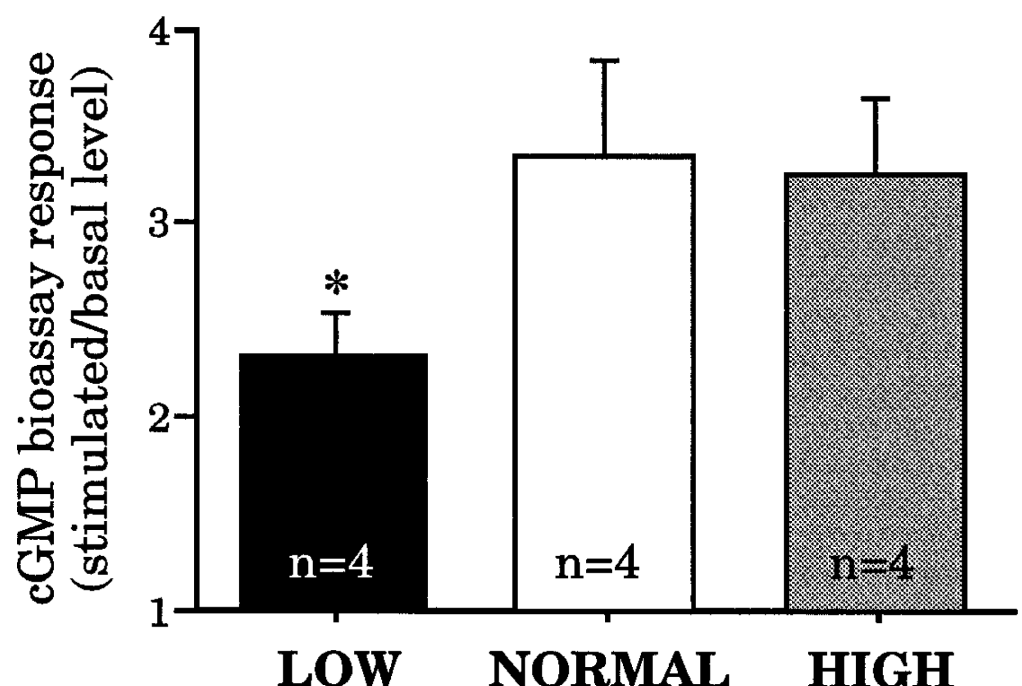

Figure 3.

GCC-mediated bioassay responses of colonic tissue isolated from rats maintained on low-, normal-, or high-salt diets. Each bar shows the fold-increase in cGMP levels when tissue explants are challenged with STa. Responses are significantly reduced in rats from the lowsalt group $(* P<0.04$ compared with control). The basal levels of cGMP were $6.8 \pm 0.42$, $7.39 \pm 0.45$, and $7.37 \pm 0.39 \mathrm{pmol} / \mathrm{mg}$ protein in the low-, normal-, and high-salt groups, respectively. Although the average basal level in the low-salt group was less than that of either of the other two treatment groups, the difference was not statistically significant $(P=$ $0.25)$. 


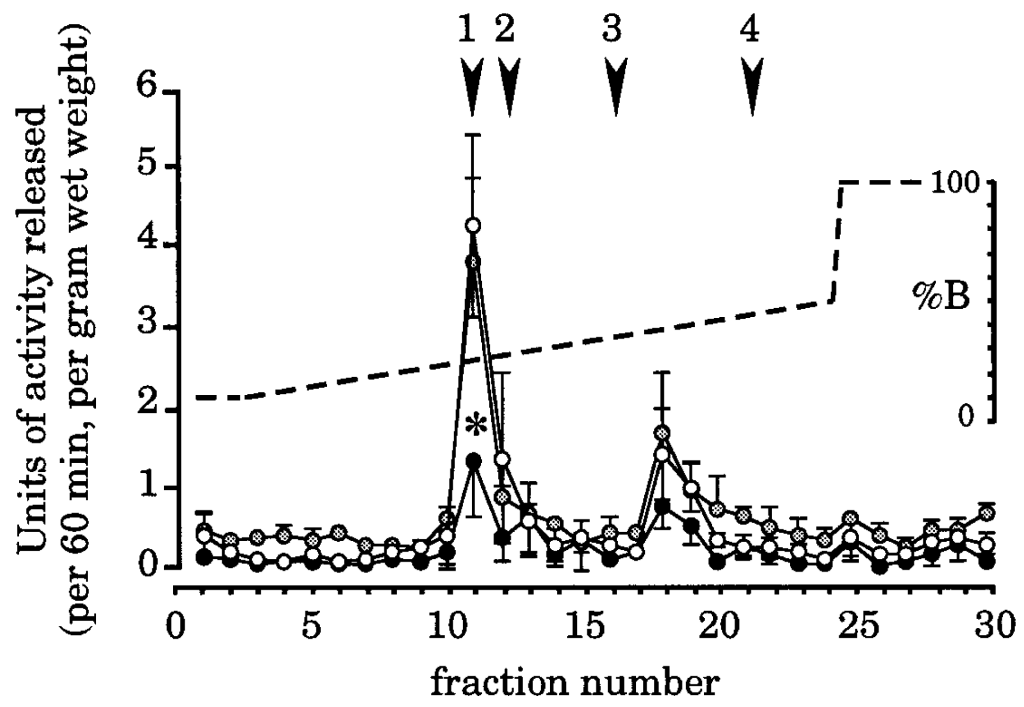

Figure 4.

Colonic explants release two peaks of biological activity that can be separated by HPLC. Activity was determined by applying an aliquot of each fraction to T84 cells. One unit is defined as the amount of material that increases the cGMP level in a well of confluent cells by 1 pmol/30 minutes. Arrowheads indicate the retention times of standards (1, guanylin 15; 2, uroguanylin; 3, STa; 4, proguanylin). The most prominent peak coelutes with the guanylin standard. Secretion of this material is significantly suppressed in rats from the low-salt group ( $* P<0.04$ compared with control). A second peak of unknown identity elutes in fraction 18. Secretion of this material is also suppressed in low-salt animals, although the statistical significance of the effect is slightly less $(P=0.059)$. Low salt; $\bigcirc$, normal salt; $\bigcirc$, high salt. 